\title{
Ribosomal Ribonucleic Acid Similarities in the Classification of Rhodococcus and Related Taxa
}

\author{
By M. MORDARSKI, ${ }^{1}$ M. GOODFELLOW, ${ }^{2 *}$ A. TKACZ, ${ }^{1}$ \\ G. PULVERER ${ }^{3}$ AND K.P. SCHAAL ${ }^{3}$ \\ ${ }^{1}$ Department of Biosynthesis, Institute of Immunology and Experimental Therapy, \\ Wroctaw, Poland \\ ${ }^{2}$ Department of Microbiology, The Medical School, The University, \\ Newcastle upon Tyne NE1 7RU \\ ${ }^{3}$ Institute of Hygiene, University of Cologne, Cologne, Federal Republic of Germany
}

(Received 3 December 1979)

\begin{abstract}
Duplexes were prepared between ${ }^{14} \mathrm{C}$-labelled rRNA from both Rhodococcus equi $\mathrm{C} 7$ and Rhodococcus rhodochrous N54 and DNA from 16 actinomycetes representing the genera Rhodococcus, Mycobacterium, Nocardia, Saccharopolyspora and Streptomyces. The relationships between the organisms were determined by plotting the temperature at which $50 \%$ of the duplex was denatured $\left(T_{m(\epsilon)}\right)$ against the percentage of rRNA binding $\left(\mu \mathrm{g}{ }^{14} \mathrm{C}\right.$-labelled rRNA duplexed per $100 \mu \mathrm{g}$ filter-bound DNA). All of the strains formed stable duplexes but each organism occupied a definite area on the rRNA similarity map. All of the organisms share a close phylogenetic relationship but representatives of the genera Rhodococcus, Mycobacterium, Nocardia and Streptomyces fell into four recognizable clusters on the similarity map. These data support and extend current trends in the classification of Rhodococcus and allied taxa. The guanine plus cytosine content of the DNA from the test strains was within the range $69 \cdot 3$ to $76.9 \mathrm{~mol} \%$.
\end{abstract}

\section{INTRODUCTION}

The genus Rhodococcus (Zopf, 1891) was reintroduced by Goodfellow \& Alderson (1977) to accommodate certain actinomycetes previously classified in genera such as Corynebacterium, Gordona, Jensenia, Mycobacterium and Nocardia. Numerical phenetic surveys and chemotaxonomic studies have led to significant improvements in the classification of Rhodococcus, Corynebacterium, Mycobacterium and Nocardia (Goodfellow \& Minnikin, 1977, 1978; Jones, 1975, 1978; Keddie \& Cure, 1978; Minnikin \& Goodfellow, 1976, 1980; Minnikin et al., 1978) and to the recognition of the 'aurantiaca' taxon (Goodfellow et al., 1978) but have shed little light on the evolutionary relationships of these taxa. The chemical evidence indicates that these taxa are closely related, as representative strains contain mycolic acids, have similar fatty acid and polar lipid compositions (Minnikin \& Goodfellow, 1980; Minnikin et al., 1978) and possess a meso-diaminopimelic acid-containing peptidoglycan associated with an arabinogalactan (wall chemotype IV; Lechevalier \& Lechevalier, 1970). Also, the guanine plus cytosine content of the DNA from rhodococci, mycobacteria and nocardiae is relatively high ( $>59 \mathrm{~mol} \% \mathrm{GC}$ ) and can be distinguished from that of true corynebacteria ( 48 to $59 \mathrm{~mol} \% \mathrm{GC}$; see, for example, Crombach, 1978; Minnikin et al., 1978; Mordarski et al., 1978).

The 10 species in the genus Rhodococcus were recognized primarily on the results of numerical phenetic and chemical studies (Goodfellow \& Alderson, 1977; Rowbotham \& 
Cross, 1977). DNA:DNA pairing data support the numerical classification but are of little value in establishing relationships between Rhodococcus species, or between these species and those of related taxa, as strains in the various homology groups have little DNA in common (Bradley \& Mordarski, 1976; Mordarski et al., 1976, 1977, 1978, 1980). Clearly, additional taxonomic methods are required to determine the phylogenetic relationships between such genetically diverse taxa.

It is now well established that the base sequences of rRNA cistrons are more highly conserved than most of the genes forming the bacterial genome (Doi \& Igarashi, 1965; Dubnau et al., 1965; Moore \& McCarthy, 1967; Takahashi et al., 1967) and that similarities in nucleotide sequences of rRNA preparations provide a means of establishing relationships among representatives of diverse bacterial taxa (Moore \& McCarthy, 1967, 1969; Johnson et al., 1970; Pace \& Campbell, 1971 $a, b$; De Smedt \& De Ley, 1977). Such studies have also been invaluable in clarifying the structure of large and heterogeneous taxa such as Clostridium (Johnson \& Francis, 1975) and Pseudomonas (Palleroni et al., 1973).

The present experiments on rRNA:DNA pairing were designed to examine the homogeneity of the genus Rhodococcus and its evolutionary relationships with the genera $M y c o-$ bacterium, Nocardia, Saccharopolyspora and Streptomyces.

\section{METHODS}

Test strains and growth conditions. The strains and their sources are listed in Table 1. More detailed histories of strains can be found elsewhere (Goodfellow, 1971; Goodfellow \& Alderson, 1977; Shirling \& Gottlieb, 1968, 1972). The cultivation conditions, harvesting procedure and methods of isolating purified DNA have been described previously (Mordarski et al., 1977).

Preparation of ${ }^{14} \mathrm{C}$-labelled $r R N A$. $\left[2-{ }^{14} \mathrm{C}\right]$ Uracil (Nuclear Research Institute, Swierk, Poland; specific activity 310 to $470 \mathrm{GBq} \mathrm{mol}^{-1}$ ) was added to inoculated modified Sauton's medium to give $74 \mathrm{kBq} \mathrm{ml}^{-1}$. After growth, harvested organisms $(20 \mathrm{~g}$ wet wt) were washed three times in $60 \mathrm{ml}$ buffer $(0.01 \mathrm{M}$-Tris $/ \mathrm{HCl}$, $0.01 \mathrm{M}-\mathrm{MgCl}_{2}, 0.01 \mathrm{M}-\mathrm{KCl}, \mathrm{pH} 7 \cdot 2$ ) and RNA was isolated after Moore \& McCarthy (1967). Thus, organisms were suspended in $20 \mathrm{ml}$ buffer ( $0.01 \mathrm{M}-\mathrm{Tris} / \mathrm{HCl}, 0.01 \mathrm{M}-\mathrm{MgCl}_{2}, 0.01 \mathrm{M}-\mathrm{KCl}, 10 \mu \mathrm{g}$ DNAase $\left.\mathrm{ml}^{-1}, \mathrm{pH} 7 \cdot 2\right)$ and disrupted by passage through a French pressure cell (140 MPa), or in a Brown disintegrator. In the latter case, the biomass was treated with an RNAase inhibitor, either Bentonite $\left(1 \mathrm{mg} \mathrm{ml}^{-1}\right)$ or polyvinylsulphate $\left(10 \mu \mathrm{g} \mathrm{ml}^{-1}\right)$, together with DNAase at $\mathrm{pH} 7.5$ before disruption; in the former, the inhibitor was added after disruption. In each case, the resultant mixture was treated with sodium dodecyl sulphate (final concentration $1 \%, \mathrm{w} / \mathrm{v}$ ) and shaken twice at room temperature for $5 \mathrm{~min}$ with 1 vol. phenol saturated with water; the RNA was precipitated from the aqueous phase with $2 \mathrm{vol}$. cold $95 \%(\mathrm{v} / \mathrm{v})$ ethanol and collected by centrifugation. The crude RNA preparation was treated with DNAase $\left(10 \mu \mathrm{g} \mathrm{ml}^{-1}\right)$, incubated at $37^{\circ} \mathrm{C}$ for $15 \mathrm{~min}$, treated with Pronase $\left(50 \mu \mathrm{g} \mathrm{ml}^{-1}\right)$ and incubated for a further $15 \mathrm{~min}$. The mixture was then treated once again with aqueous phenol, centrifuged and the RNA was precipitated with $95 \%$ ethanol. Deproteinization with phenol was repeated three times and the purified RNA was resuspended in SSC buffer $(0.15 \mathrm{M}-\mathrm{NaCl}, 0.015 \mathrm{M}-$ trisodium citrate, $\mathrm{pH} 7 \cdot 0$ ).

The purified RNA was fractionated by sucrose gradient centrifugation after McConkey (1967). RNA (about $1 \mathrm{mg}$ ) was placed on the surface of a $21 \mathrm{ml}$ sucrose linear gradient $[15$ to $30 \%(\mathrm{w} / \mathrm{v})$ sucrose in $0.1 \mathrm{M}$ sodium acetate buffer with $0.05 \mathrm{M}-\mathrm{NaCl}, \mathrm{pH} 5$ to $5 \cdot 1$ ] and centrifuged in a Janetzki VAC 60 ultracentrifuge at $108000 \mathrm{~g}$ for $20 \mathrm{~h}$ at $4{ }^{\circ} \mathrm{C}$. After centrifugation, samples from each of the collected fractions were assayed for radioactivity to locate the RNA. The $16 \mathrm{~S}$ and $23 \mathrm{~S}$ fractions were collected separately, dialysed three times against 41 of $2 \times \mathrm{SSC}$ buffer at $4{ }^{\circ} \mathrm{C}$ and stored at $-12^{\circ} \mathrm{C}$.

The rRNA :DNA pairing experiments were carried out using the 23S rRNA fractions. Labelled reference rRNA was prepared from Rhodococcus equi C7 and Rhodococcus rhodochrous N54; the specific activities of the samples were 4161 and 2033 c.p.m. $\mu \mathrm{g}^{-1}$, respectively.

Preparation of DNA. High molecular weight DNA was prepared using the modification of the method of Saito \& Miura (1963) described by Mordarski et al. (1976). Single-stranded DNA $\left(30 \mu \mathrm{g} \mathrm{cm}^{-2}\right)$ was immobilized on nitrocellulose membrane filters (Schleicher \& Schüll; $50 \mathrm{~mm}$ diam.; pore size $0.45 \mu \mathrm{m}$ ).

Analysis of DNA base composition. The mol \% GC of DNA preparations was determined by the thermal denaturation method (Marmur \& Doty, 1962).

$r R N A: D N A$ pairing and thermal stability of duplexes. The extent of nucleotide pairing and duplex stability were determined after De Ley \& De Smedt $(1975) .{ }^{14} \mathrm{C}$-labelled rRNA $(6 \mu \mathrm{g})$ was incubated in $1 \mathrm{ml}$ of $2 \times \mathrm{SSC}$ in $20 \%(\mathrm{v} / \mathrm{v})$ formamide with immobilized DNA $\left(30 \mu \mathrm{g} \mathrm{cm}^{-2}\right)$ for $18 \mathrm{~h}$ at $50{ }^{\circ} \mathrm{C}$. After washing, the 
Table 1. Test strains used, their source, DNA base composition, and properties of the $D N A$ : $r R N A$ duplexes with two Rhodococcus ${ }^{14} C$-labelled $r R N A$ reference systems

\begin{tabular}{|c|c|c|c|c|c|c|c|}
\hline \multirow[b]{2}{*}{ Lab. no. } & \multirow[b]{2}{*}{$\begin{array}{l}\text { Test organism } \\
\text { used for DNA } \\
\text { preparation }\end{array}$} & \multirow[b]{2}{*}{ Source $†$} & \multirow[b]{2}{*}{$\begin{array}{l}\text { Mol } \% \\
\text { GC }\end{array}$} & \multicolumn{2}{|c|}{ R. equi C7 } & \multicolumn{2}{|c|}{$\begin{array}{l}\text { R. rhodochrous } \\
\text { N54 }\end{array}$} \\
\hline & & & & $\begin{array}{c}\% \\
\text { binding }\end{array}$ & $\begin{array}{l}T_{m(e)} \\
\left({ }^{\circ} \mathrm{C}\right)\end{array}$ & $\begin{array}{c}\% \\
\text { binding }\end{array}$ & $\begin{array}{l}T_{m(e)} \\
\left({ }^{\circ} \mathrm{C}\right)\end{array}$ \\
\hline *C600 & Escherichia coli & NCTC 9001 & $51 \cdot 5$ & 0.011 & $69 \cdot 5$ & 0.07 & $74 \cdot 0$ \\
\hline *M377 & $\begin{array}{l}\text { Mycobacterium } \\
\text { chelonei }\end{array}$ & NCTC 946 & $72 \cdot 5$ & 0.06 & $72 \cdot 5$ & 0.04 & $77 \cdot 0$ \\
\hline *M93 & $M$. fortuitum & NCTC 10394 & $69 \cdot 5$ & $0 \cdot 10$ & $75 \cdot 5$ & 0.08 & $76 \cdot 0$ \\
\hline *M101 & M. smegmatis & NCTC 10265 & $73 \cdot 4$ & $0 \cdot 10$ & $73 \cdot 5$ & $0 \cdot 10$ & $76 \cdot 0$ \\
\hline *N667 & Nocardia amarae & $\begin{array}{l}\text { M.P. Lechevalier, } \\
\text { IMRU W3960 }\end{array}$ & $71 \cdot 0$ & $0 \cdot 22$ & $73 \cdot 0$ & $0 \cdot 22$ & $73 \cdot 0$ \\
\hline *N317 & $N$. asteroides & ATCC 19247 & $74 \cdot 6$ & $0 \cdot 24$ & $73 \cdot 5$ & $0 \cdot 23$ & $74 \cdot 5$ \\
\hline$* N 36$ & N. otitidis-caviarum & NCTC 1934 & $71 \cdot 7$ & $0 \cdot 28$ & $73 \cdot 5$ & $0 \cdot 20$ & $76 \cdot 0$ \\
\hline *N744 & $\begin{array}{l}\text { Rhodococcus } \\
\text { coprophilus }\end{array}$ & NCIB 11211 & $69 \cdot 3$ & $0 \cdot 19$ & $74 \cdot 0$ & $0 \cdot 25$ & $76 \cdot 5$ \\
\hline$* \mathrm{C} 7$ & R. equi & NCTC 1621 & $70 \cdot 4$ & $0 \cdot 23$ & $74 \cdot 5$ & ND & ND \\
\hline N829 & $R$. equi group & R. E. Gordon, 588 & $70 \cdot 9$ & $0 \cdot 23$ & $74 \cdot 0$ & $0 \cdot 24$ & $76 \cdot 5$ \\
\hline *N11 & R. erythropolis & NCIB 9158 & $70 \cdot 6$ & $0 \cdot 25$ & $74 \cdot 0$ & $0 \cdot 20$ & $78 \cdot 0$ \\
\hline$* N 54$ & $R$. rhodochrous & NCIB 11147 & $69 \cdot 5$ & $0 \cdot 22$ & $74 \cdot 5$ & 0.23 & $78 \cdot 5$ \\
\hline *N361 & R. ruber & M. Tsukamura, M-1 & $72 \cdot 3$ & $0 \cdot 25$ & $77 \cdot 0$ & $0 \cdot 27$ & $77 \cdot 5$ \\
\hline *N745 & $\begin{array}{l}\text { Saccharopolyspora } \\
\text { hirsuta }\end{array}$ & NCIB 11079 & $76 \cdot 9$ & $0 \cdot 21$ & $72 \cdot 0$ & $0 \cdot 17$ & $74 \cdot 5$ \\
\hline *N884 & $\begin{array}{l}\text { Streptomyces } \\
\text { griseus }\end{array}$ & NCTC 3236 & $74 \cdot 4$ & $0 \cdot 14$ & $72 \cdot 5$ & $0 \cdot 12$ & $77 \cdot 8$ \\
\hline *N915 & S. indigocolor & ISP 5432 & $74 \cdot 7$ & $0 \cdot 18$ & $73 \cdot 0$ & $0 \cdot 19$ & $76 \cdot 5$ \\
\hline *N916 & S. toyocaensis & ISP 5030 & $71 \cdot 0$ & $0 \cdot 25$ & $72 \cdot 0$ & $0 \cdot 20$ & $76 \cdot 5$ \\
\hline
\end{tabular}

ND, Not determined.

* Type strain.

$\dagger$ ATCC, American Type Culture Collection, Rockville, Md, U.S.A.; ISP, International Streptomyces Project (see Shirling \& Gottlieb, 1968, 1972); NCIB, National Collection of Industrial Bacteria, Aberdeen, Scotland; NCTC, National Collection of Type Cultures, London; R. E. Gordon and M. P. Lechevalier, Rutgers University, New Brunswick, N.J., U.S.A.; M. Tsukamura, The National Chubu Hospital, Obu, Aichi, Japan.

membrane filters were treated with RNAase $(250 \mu \mathrm{g})$ in $2 \mathrm{ml}$ of $2 \times \mathrm{SSC}$ buffer at $37^{\circ} \mathrm{C}$ for $1 \mathrm{~h}$. The thermal stability of duplexes formed between filter-bound DNA and reference rRNA preparations was determined from the $T_{m(e)}$ values, i.e. the temperature at which half of the paired rRNA becomes dissociated and eluted from test DNA bound to the filter. Thus, the thermal stability of duplexes was determined by eluting dried filters with $1.5 \times \mathrm{SSC}$ in $20 \%(\mathrm{v} / \mathrm{v})$ formamide in $5{ }^{\circ} \mathrm{C}$ steps from 60 to $90{ }^{\circ} \mathrm{C}$. The amount of material released at each step was counted in a liquid scintillation counter (Mark 1, Nuclear Chigaco) for $50 \mathrm{~min}$. The total amount of bound ${ }^{14} \mathrm{C}$-labelled rRNA, expressed as $\mu \mathrm{g}$ rRNA per $100 \mu \mathrm{g}$ DNA retained on filters, was called the 'percentage of rRNA binding'. The DNA remaining on membranes was released using the method of Meys \& Schilperoort (1971) and the amount was determined chemically after Burton (1956).

\section{RESULTS}

DNA base compositions. The test strains fell within the range $69 \cdot 3$ to $76.9 \mathrm{~mol} \% \mathrm{GC}$ (Table 1).

$r R N A: D N A$ pairing and thermal stability of duplexes. The ${ }^{14} \mathrm{C}$-labelled $\mathrm{rRNAs}$ from the reference strains $R$. equi $\mathrm{C7}$ and $R$. rhodochrous $\mathrm{N} 54$ were clearly separated on sucrose gradients (Fig. 1). 23S rRNA similarity was expressed both as $T_{m(e)}$ and as percentage of rRNA binding (Table 1), as the latter depends not only on the actual rRNA homology but also on the size of the genome, its state of replication and the number of rRNA cistrons in the genome (De Smedt \& De Ley, 1977). A few examples of melting point determinations are shown in Fig. 2. The correlation between the two sets of data was revealed by 


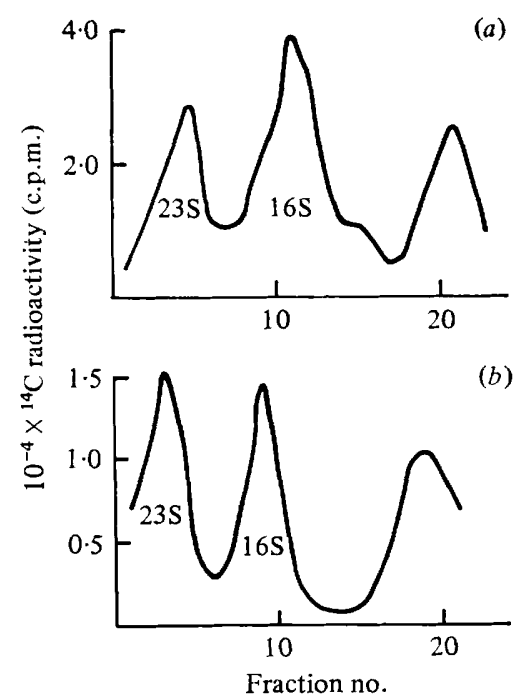

Fig. 1

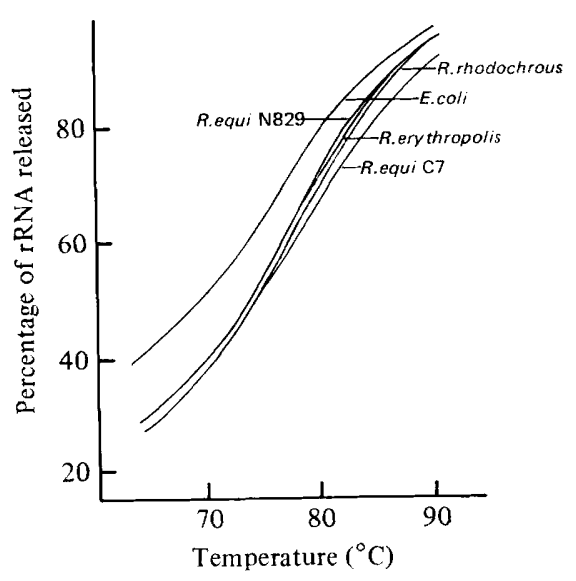

Fig. 2

Fig. $1 .{ }^{14} \mathrm{C}$-labelled rRNA distributions in a linear 15 to $30 \%$ sucrose gradient: (a) Rhodococcus equi C7; (b) Rhodococcus rhodochrous N54.

Fig. 2. Denaturation curves of duplexes between $23 \mathrm{~S}^{14} \mathrm{C}$-labelled rRNA from Rhodococcus equi $\mathrm{C} 7$ and filter-bound DNA from other Rhodococcus strains and E. coli.

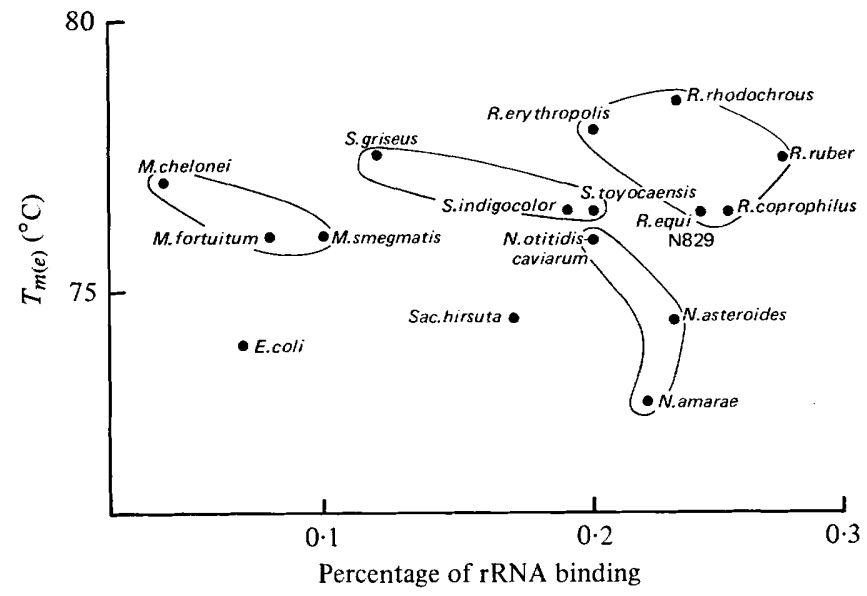

Fig. 3. Similarity map of duplexes between $23 \mathrm{~S}{ }^{14} \mathrm{C}$-labelled rRNA from Rhodococcus rhodochrous N54 and DNA from representative strains of Mycobacterium, Nocardia, Rhodococcus, Saccharopolyspora and Streptomyces. $T_{m(e)}$ and 'percentage of rRNA binding' are defined in Methods. Strains belonging to genera recognized on the basis of phenotypic properties are surrounded by a closed line. The lines do not represent sharp generic boundaries as the shape and dimensions of the defined taxa are limited by the numbers of strains examined.

plotting, for each reference system, $T_{m(e)}$ against percentage of rRNA binding (Figs 3 and 4).

In rRNA similarity maps each strain has a fixed position. It can be seen from Figs 3 and 4 that while all of the test strains form stable duplexes they can be divided into four groups when the amount of binding is also taken into account. The groups contain the rhodococci, mycobacteria, nocardiae and streptomycetes, respectively. The position of Saccharopolyspora hirsuta N745 is equivocal as it clusters with the streptomycetes in one reference system (Fig. 4) but does not fall into any of the four groups in the other reference system (Fig. 3). 


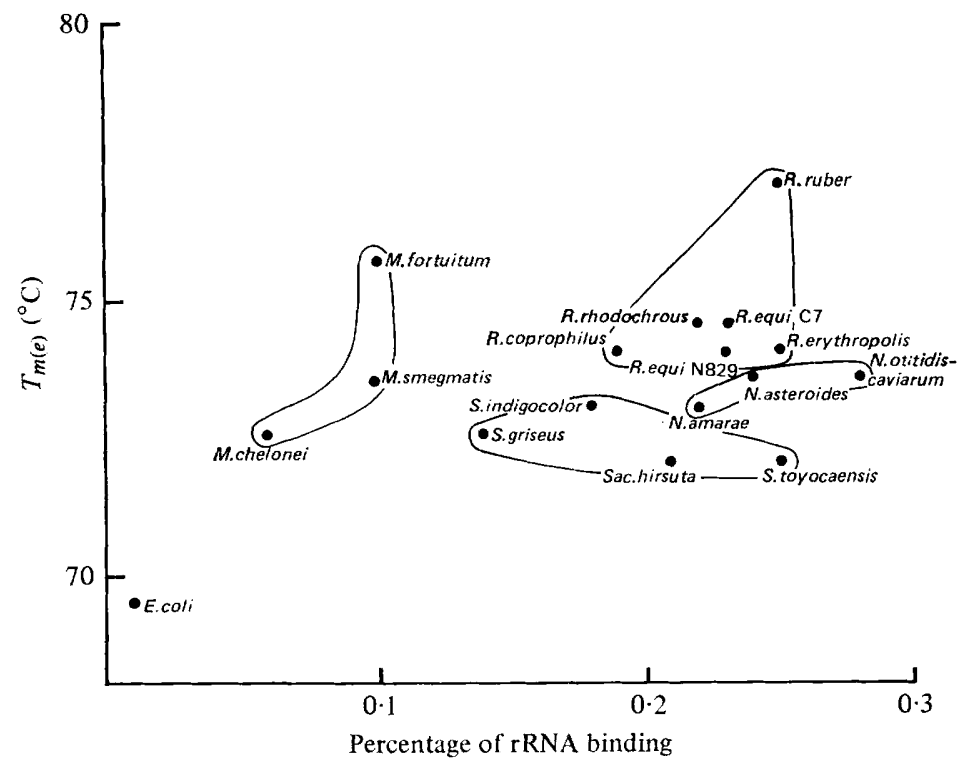

Fig. 4. Similarity map of duplexes between $23 \mathrm{~S}{ }^{14} \mathrm{C}$-labelled rRNA from Rhodococcus equi $\mathrm{C} 7$ and DNA from representative strains of Mycobacterium, Nocardia, Rhodococcus, Saccharopolyspora and Streptomyces. For further details, see legend to Fig. 3.

\section{DISCUSSION}

The results of the present nucleic acid pairing experiments have made it possible to establish the phylogenetic relationships between actinomycetes that show little genetic similarity in DNA : DNA pairing assays (Bradley \& Mordarski, 1976; Mordarski et al., $1976,1977,1978,1980$ ). These preliminary data, therefore, provide yet further evidence that the segment of the bacterial genome coding for rRNA is more conserved in the course of evolution than the bulk of the genome (Doi \& Igarashi, 1965; Dubnau et al., 1965) and strongly suggest that a close phylogenetic relationship exists between Rhodococcus, Mycobacterium, Nocardia, Saccharopolyspora and Streptomyces. Thus, all of the representatives of these taxa formed stable duplexes in both the $R$. equi and $R$. rhodochrous reference systems. Additional comparative studies using representatives of other taxa are, however, needed to determine whether the actinomycetes form a natural group. The base composition data help to confirm that the actinomycetes are rich in guanine and cytosine (Mordarski et al., 1978).

It was encouraging that the representatives of the genera Rhodococcus, Mycobacterium, Nocardia and Streptomyces occupied recognizable areas on the similarity maps. Nevertheless, additional representative strains should be examined to confirm the position of these taxa on similarity maps and to establish the shape and size of the area occupied by each of the genera. It will also be interesting to see if mycolic acid-containing actinomycetes with a wall chemotype IV have a closer affinity with one another than with related actinomycetes which lack mycolic acids (Goodfellow \& Minnikin, 1977, 1978; Minnikin \& Goodfellow, 1980). The preliminary nature of these data, however, makes it premature to try to correlate rRNA similarities with phenotypic properties, though there is some evidence that such comparisons may provide a basis for selecting phenotypically conserved characters which represent cistrons that are partially conserved (De Smedt \& De Ley, 1977; Johnson \& Francis, 1975).

Estimates of rRNA similarities can also be of value in determining the relationships of misclassified or poorly classified strains (De Smedt \& De Ley, 1977). Such studies should, 
therefore, be of value in establishing the status of strains such as Arthrobacter variabilis, Corynebacterium equi, $C$. hoagi and $C$. hydrocarboclastus which have many phenotypic characters in common with representatives of Corynebacterium sensu stricto and Rhodococcus (Minnikin et al., 1978; Minnikin \& Goodfellow, 1980). The proposal to transfer C. equi to the genus Rhodococcus (Goodfellow \& Alderson, 1977) is not contradicted by the rRNA similarity data and is supported both by the present and past base composition studies (Yamada \& Komagata, 1970). Thus, the base ratio estimations for $R$. equi C7 and N829 are within the 65.1 to $72.7 \mathrm{~mol} \% \mathrm{GC}$ range expected for rhodococci using the thermal denaturation method (Mordarski et al., 1980).

The base composition and rRNA :DNA similarity data support the integrity of the genus Rhodococcus and its separation from related mycolic acid-containing actinomycetes classified in the genera Mycobacterium and Nocardia. Further DNA:rRNA pairing experiments are, however, required to confirm these preliminary observations and to determine the relationships between true corynebacteria and rhodococci.

\section{REFERENCES}

Bradley, S. G. \& Mordarski, M. (1976). Association of polydeoxyribonucleotides of deoxyribonucleic acids from nocardioform bacteria. In The Biology of the Nocardiae, pp. 310-336. Edited by M. Goodfellow, G. H. Brownell \& J. A. Serrano. London: Academic Press.

Burton, K. (1956). A study of the conditions and mechanism of the diphenylamine reaction for the colorimetric estimation of deoxyribonucleic acid. Biochemical Journal 62, 315-323.

Crombach, W. H. J. (1978). DNA base ratios and DNA hybridisation studies of coryneform bacteria, mycobacteria and nocardiae. In Coryneform Bacteria, pp. 161-179. Edited by I. J. Bousfield \& A. G. Callely. London: Academic Press.

DE LEY, J. \& DE SMEDT, J. (1975). Improvements of the membrane filter method for DNA:rRNA hybridization. Antonie van Leeuwenhoek 41, 287307.

DE SMedt, J. \& DE LeY, J. (1977). Intra- and intergeneric similarities of Agrobacterium ribosomal ribonucleic acid cistrons. International Journal of Systematic Bacteriology 27, 222-240.

Dor, R. H. \& Igarashi, R. T. (1965). Conservation of ribosomal and messenger ribonucleic acid cistrons in Bacillus species. Journal of Bacteriology 90, 384-390.

Dubnau, D., Smith, I., Morell, P. \& Marmur, J. (1965). Gene conservation in Bacillus species. I. Conserved genetic and nucleic acid sequence homologies. Proceodings of the National Academy of Sciences of the United States of America 54, 491-498.

Goodfellow, M. (1971). Numerical taxonomy of some nocardioform bacteria. Journal of General Microbiology 69, 33-80.

Goodfellow, M. \& Alderson, G. (1977). The actinomycete genus Rhodococcus: a home for the 'rhodochrous' complex. Journal of General Microbiology 100, 99-122.

Goodfellow, M. \& MinNiKin, D. E. (1977). Nocardioform bacteria. Annual Review of Microbiology 31, 159-180.

Goodfellow, M. \& MinNikin, D. E. (1978). Numerical and chemical methods in the classifica- tion of Nocardia and related taxa. Zentralblatt für Bakteriologie, Parasitenkunde, Infektionskrankheiten und Hygiene (Abteilung I), Supplement 6, 43-51.

Goodfellow, M., Orlean, P. A. B., Collins, M. D., Alshamaony, L. \& Minnikin, D. E. (1978). Chemical and numerical taxonomy of strains received as Gordona aurantiaca. Journal of General Microbiology 109, 57-68.

Johnson, J. L. \& Francis, B. S. (1975). Taxonomy of the clostridia: ribosomal ribonucleic acid homologies among the species. Journal of General Microbiology 88, 229-244.

Johnson, J. L., Anderson, R. S, \& Ordal, E. J. (1970). Nucleic acid homologies among oxidasenegative Moraxella species. Journal of Bacteriology 101, 568-573.

JONES, D. (1975). A numerical taxonomic study of coryneform and related bacteria. Journal of General Microbiology 87, 52-96.

JoNES, D. (1978). An evaluation of the contributions of numerical taxonomic studies to the classification of coryneform bacteria. In Coryneform Bacteria, pp. 13-46. Edited by I. J. Bousfield \& A. G. Callely. London: Academic Press.

Keddie, R. M. \& Cure, G. L. (1978). Cell wall composition of coryneform bacteria. In Coryneform Bacteria, pp. 47-83. Edited by I. J. Bousfield \& A. G. Callely. London: Academic Press.

LecheValier, M. P. \& Lechevalier, H. A. (1970). Chemical composition as a criterion in the classification of aerobic actinomycetes. International Journal of Systematic Bacteriology 20, 435-444.

MCCONKEY, E. H. (1967). The fractionation of RNA's by sucrose gradient centrifugation. Methods in Enzymology 12, 620-634.

Marmur, J. \& Doty, P. (1962). Determination of base composition of deoxyribonucleic acid from its thermal denaturation temperature. Journal of Molecular Biology 5, 109-118.

Meys, W. H. \& Schilperoort, R. A. (1971). Determination of the amount of DNA on nitrocellulose membrane filters. FEBS Letters 12 , 166-168. 
Mrnnikin, D. E. \& Goodfellow, M. (1976). Lipid composition in the classification and identification of nocardiae and related taxa. In The Biology of the Nocardiae, pp. 160-219. Edited by M. Goodfellow, G. H. Brownell \& J. A. Serrano. London: Academic Press.

Minnikin, D. E. \& Goodfellow, M. (1980). Lipid composition in the classification and identification of acid fast bacteria. In Microbiological Classification and Identification, pp. 189-256. Edited by M. Goodfellow \& R. G. Board. London: Academic Press.

Minnikin, D. E., Goodfellow, M. \& Collins, M. D. (1978). Lipid composition in the classification and identification of coryneform and related taxa. In Coryneform Bacteria, pp. 85-160. Edited by I. J. Bousfield \& A. G. Callely. London: Academic Press.

Moore, R. L. \& McCarthy, B. J. (1967). Comparative study of ribosomal ribonucleic acid cistrons in enterobacteria and myxobacteria. Journal of Bacteriology 94, 1066-1074.

Moore, R. L. \& McCarthy, B. J. (1969). Base sequence homology and renaturation studies of the deoxyribonucleic acid of extremely halophilic bacteria. Journal of Bacteriology 99, 255-262.

Mordarski, M., Szyba, K., Pulverer, G. \& GoOdFellow, M. (1976). Deoxyribonucleic acid reassociation in the classification of the rhodochrous' complex and allied taxa. Journal of General Microbiology 94, 235-245.

Mordarski, M., Goodfellow, M., Szyba, K., Pulverer, G. \& TkaCz, A. (1977). Classification of the 'rhodochrous' complex and allied taxa based upon deoxyribonucleic acid reassociation. International Journal of Systematic Bacteriology 27, 31-37.

Mordarski, M., Goodfellow, M., Szyba, K., Pulverer, G. \& Tkacz, A. (1978). Deoxyribonucleic acid base composition and homology studies on Rhodococcus and allied taxa. Zentralblatt für Bakteriologie, Parasitenkunde, Infektionskrankheiten und Hygiene (Abteilung I), Supplement 6, 99-106.

Mordarski, M., Goodfellow, M., Szyba, K., Tkacz, A., Pulverer, G. \& SchaAl, K. P. (1980).
Deoxyribonucleic acid reassociation in the classification of the genus Rhodococcus. International Journal of Systematic Bacteriology (in the Press).

Pace, B. \& Campbell, L. L. (1971a). Homology of ribosomal ribonucleic acid of Desulfovibrio species with Desulfovibrio vulgaris. Journal of Bacteriology 106, 717-719.

Pace, B. \& Campbell, L. L. (1971 $b)$. Homology of ribosomal ribonucleic acid of diverse bacterial species with Escherichia coli and Bacillus stearothermophilus. Journal of Bacteriology 107, 543-547.

Palleroni, N. J., Kunisawa, R., Contcpoulou, R. \& Doudoroff, M. (1973). Nucleic acid homologies in the genus Pseudomonas. International Journal of Systematic Bacteriology 23, 333-339.

Row botham, T. J. \& Cross, T. (1977). Rhodococcus coprophilus sp.nov.: an aerobic nocardioform actinomycete belonging to the 'rhodochrous' complex. Journal of General Microbiology 100, 123-138

Saito, H. \& Miura, K. I. (1963). Preparation of transforming deoxyribonucleic acid by phenol treatment. Biochimica et biophysica acta $\mathbf{7 2}$, 619-629.

Shirling, E. B. \& Gottlieb, D. (1968). Cooperative description of type cultures of Streptomyces. II. Species descriptions from first study. International Journal of Systematic Bacteriology 18, 69-189.

Shirling, E. B. \& Gottlieb, D. (1972). Cooperative description of type strains of Streptomyces. V. Additional descriptions. International Journal of Systematic Bacteriology 22, 265-394.

Takahashi, H., SaIto, H. \& Ikeda, Y. (1967). Species specificity of the ribosomal RNA cistrons in bacteria. Bioctimica et biophysica acta 134, $124-133$.

Yamada, K. \& Komagata, K. (1970). Taxonomic studies on coryneform bacteria. III. DNA base composition of coryneform bacteria. Journal of General and Applied Microbiology 16, 215-224.

Z.opf, W. (1891). Über Ausscheidung von Fettfarbstoffen (Lipochromen) seitens gewisser Spaltpilze. Berichte der Deutschen botanischen Gesellschoft $\mathbf{9}$, $22-28$. 